Judy Quinn

\title{
Anonymity and the Textual Construction of Authority in Prosimetrum
}

\begin{abstract}
The ways in which anonymity participates in the textual construction of authority is the focus of this chapter, which proceeds through an investigation of the literary effects that were achieved in two different kinds of medieval Icelandic prosimetrum, examples which demonstrate how literate authors exploited the potential of orally transmitted poetry to enrich their prose. The case studies are drawn from Gylfaginning by Snorri Sturluson, where anonymous poetry simulating the speech of gods is quoted within a treatise by a named author, and porgils saga ok Hafliða, where stanzas by contemporary poets named and unnamed are quoted within an anonymous saga about a $12^{\text {th }}$-century political feud. The theoretical frame is provided by reflections on authorship by Michel Foucault and Roland Barthes which, while dating from the 1960s, still hold considerable relevance for the analysis of the competing voices of prosimetrum, especially with regard to the establishment of authority within written discourse. The notion of 'an index of truthfulness', constituted by poetic quotation around which the narration develops, is explored and it is proposed that across a wide range of discursive situations voices speaking according to conventions of poetic composition are rendered authoritative through the performance of quotation.
\end{abstract}

Keywords

Saga Prosimetrum, Anonymous Authorship, Porgils saga ok Hafliða, Gylfaginning, Roland Barthes, Michel Foucault, Skaldic Poetry, Verse Quotation

While the ground-breaking essays on authorship by Roland Barthes and Michel Foucault from the 1960s were focussed on post-medieval continental European culture, a number of their observations find illuminating parallels in the conditions of medieval Icelandic prosimetrum, where poetic voices are quoted by a voice that speaks prose. The assumption of a straightforward relationship between the authority of a text and the identity of its author, whose foundations were shaken in the 1960s, had not always been a constant and had in fact varied considerably across the centuries and across genres. In the case of medieval Iceland, anonymity sometimes guaranteed an authority that was legitimated by tradition, as seems to have been the case with anonymous eddic poetry, orally composed and orally transmitted for generations before being written down in the $13^{\text {th }}$ century. The stories of the past that flowed into the emergent literary genre of the Íslendingasögur (sagas of Icelanders) similarly derived their authority from shared cultural tradition rather than from the identities of the people who formulated the 
written texts, whose names were not routinely attached to their works. The medieval Scandinavian genres where the name of the author clearly underwrote the authority of the text include not only learned treatises, as might be expected, but also orally composed poetry in complex metres whose poets had staked their reputations on being identified by name in connection with their works in the skaldic tradition. When one kind of text is folded into another - as is the case with saga prosimetrum, where stanzas by named poets are quoted by anonymous authors - an unusual kind of authorial voice is created, one that blends the authority of skaldic tradition with the authority of the anonymous saga tradition.

In this chapter, I will focus on two very different prosimetric texts to explore the way anonymity participates in the textual construction of authority. ${ }^{1}$ Firstly I will analyse the mode of quotation of traditional anonymous poetry that simulates the speech of gods and supernatural beings within a treatise by a named author (Gylfaginning by Snorri Sturluson); and secondly, the quotation of stanzas by contemporary poets named and unnamed within an anonymous saga about a $12^{\text {th }}$-century political feud (porgils saga ok Hafliða). Together these texts reveal the complex literary effects that were achieved by medieval Icelandic prosimetrum writers as they explored the potential of harnessing the resources of orally transmitted poetry within prose narratives.

To frame the discussion, I want to begin by reflecting on a distinction made by Foucault about the different kinds of authorship that pertain to different kinds of texts. In his essay, 'What is an Author?', Foucault discusses a change in attitude that occurred during the $17^{\text {th }}$ and $18^{\text {th }}$ centuries. Before that time, he argues, some kinds of texts did not always require authors, while some conventionally did:

Even within our civilization, the same types of texts have not always required authors; there was a time when those texts which we now call "literary" (stories, folk tales, epics, and tragedies) were accepted, circulated, and valorized without any question about the identity of their author. Their anonymity was ignored because their real or supposed age was a sufficient guarantee of their authenticity. Texts, however, that we now call "scientific" (dealing with cosmology and the heavens, medicine or illness, the natural sciences or geography) were only considered truthful during the Middle Ages if the name of the author was indicated. ${ }^{2}$

Into this first category, of texts that have not required authors, we may put the written saga, narratives that were circulated and valorised in medieval Iceland, apparently without any preoccupation, at the time, about the identity of their authors. Their age, or

1 I am grateful to Lukas Rösli and Stefanie Gropper for inviting me to the workshop "The Medieval Author: A Phantasm" and to the workshop participants for discussion of an earlier version of this chapter, presented at the workshop in Tübingen in 2019.

2 Foucault 1977, p. 125. 
their traditional nature, guaranteed their authenticity as culturally valuable depictions of the distant and recent past and, as far as the written record goes, their anonymity was ignored.

Into the second category, where texts were only considered truthful if the name of the author was indicated, we may, as already mentioned, place skaldic poetry transmitted orally and then in writing with, in most cases, the name of the poet attached. While we may not wish to label this discourse 'scientific', it is characterised by exclusive access to political interaction, specialised eye-witness observation, and a kind of discursive expertise in formulating dróttkvoett praise poetry. The authors Foucault mentions in this category, Hippocrates and Pliny, were culturally and discursively a world away from Viking-Age and medieval skalds, yet the tenacious way in which skaldic poets were identified by name when their compositions were quoted indicates that their authority could be deployed in a way not dissimilar to that of classical authors. Skaldic verse had a special discursive power which was reinforced during the transition from orality to literacy, with poets maintaining their status as authorities. ${ }^{3}$ Indeed the author of the $12^{\text {th }}$-century First Grammatical Treatise equated skalds with authority: "Skáld eru höfundar allrar rynni eða máls greinar sem smiðir eða lögmenn laga" ('The scalds [sic] are authorities in all (matters touching the art of) writing or the distinction (made in) discourse, just as craftsmen (are) [in their craft] or lawyers in the laws'). ${ }^{4}$ The anonymous author of the treatise has in fact become known in scholarship as the First Grammarian, gaining a name of sorts through identification with his text. He and other medieval Icelandic authors of treatises, such as Ari borgilsson, óláfr pórðarson, and Snorri Sturluson, are more obvious candidates to be assigned to the 'scientific' category of texts.

The particular labels Foucault assigns to his categories, 'literary' and 'scientific', are naturally context-dependent and to a certain extent can be set aside when his articulation of the anonymity binary is transferred to the medieval Scandinavian cultural milieu. The usefulness of the distinction Foucault draws about pre-modern texts when applied to medieval Scandinavian works rests primarily on the concept of anonymity and with it the paradoxical authority the unnamed, tradition-bearing voice carried forward into the literate age. An example of this phenomenon, mentioned earlier, is the traditional eddic poetry preserved in GKS 2365 4to and known as the Poetic Edda. The authorial voice of eddic tradition - especially those poems introduced by a narrator would have supplied a ready storytelling model for the emergent (anonymous) voice of written saga prosimetrum, as well as there being other storytelling modes in the preliterate period we know less about which writers would also have drawn on.

3 See further Jesch 2005.

4 The First Grammatical Treatise, pp. 224-226 (with normalised spelling). 
Foucault further argued that during the course of the $17^{\text {th }}$ and $18^{\text {th }}$ centuries, the situation he described was inverted, with named authorship becoming an essential feature of 'literary' works while anonymity was increasingly favoured for texts that transmitted received wisdom:

scientific texts were accepted on their own merits and positioned within an anonymous and coherent conceptual system of established truths and methods of verification. Authentification no longer required reference to the individual who had produced them; the role of the author disappeared as an index of truthfulness [...]. ${ }^{5}$

Once again, the description of these conditions finds a ready parallel with the circumstances that must have pertained during the literarisation of saga narratives: not as a change from a former situation, as Foucault described it for continental Europe, but as the state of play in medieval Iceland during the development of a culture of alphabetic literacy. As traditional material that had been orally transmitted was transformed into saga text, we may assume it operated within "an anonymous and coherent conceptual system of established truths and methods of verification" as understood by saga audiences. It was presumably the texts' presentation of traditional material which obviated the need for identifying individual transmitters of prose narratives; the "index of truthfulness", such as it was, was tied to the transmission of skaldic poetry where the quotation of stanzas was conventionally attributed to named poets and thereby provided a mode of verification.

The force of quotations by named voices within an anonymous work is significant and amounts to a textual phenomenon of critical interest, to which I will return. In advance of that, however, I want to consider a complex Old Norse text which is distinguished by its many layers of quoted voices, where "an anonymous and coherent conceptual system of established truths" intersects with a named authorising voice. The text in question is the treatise known as the Edda, initiated, it is assumed, by Snorri Sturluson, but now extant in multiple versions that demonstrate numerous creative phases whose material traces postdate the death of the author. ${ }^{6}$ A part of the treatise dealing with pre-Christian mythology is known as Gylfaginning. It is a unique and highly experimental work, which engages at a profound level with questions of truth as it works to organise elements of traditional pre-Christian beliefs within a framework of Christian doctrine. ${ }^{7}$ It quotes eddic poetry copiously, drawing much of its authority from

$5 \quad$ Foucault 1977, p. 126.

6 For an overview of Snorri and his work, see Wanner 2008. For an overview of the variation in the manuscripts of the work, see Guðrún Nordal 2001, pp. 44-72.

7 See further my forthcoming article on Snorra Edda where some of these issues are treated in more depth: Quinn 2021. 
the anonymous conceptual system of established truths conveyed by the eddic corpus of traditional poems.

Gylfaginning is constructed as a series of nested quotations within a narrative told about King Gylfi (who identifies himself in the text as Gangleri), prefaced by paratextual material including the prologue and the rubric (in one manuscript) naming the work and its author. ${ }^{8}$ The quotations within quotations can be set out schematically as a cascading sequence of voices:

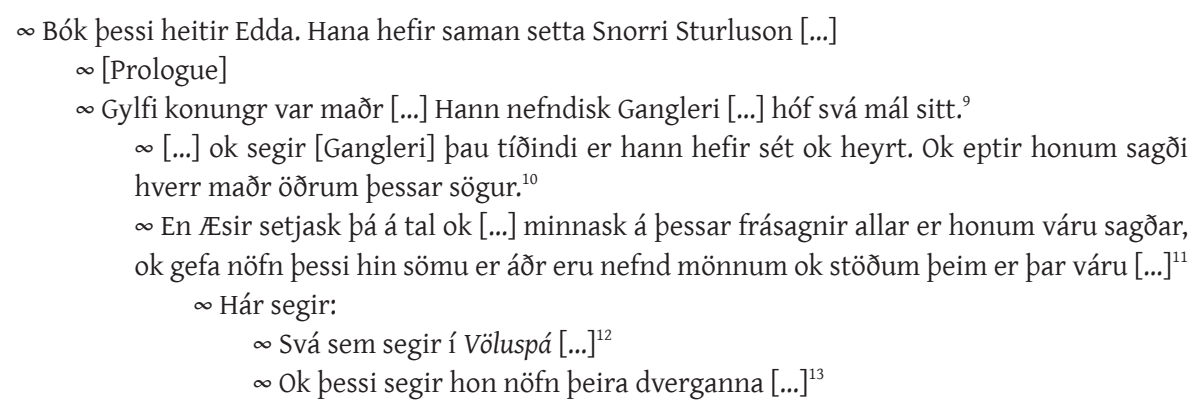

This book is called Edda. It has been compiled by Snorri Sturluson [...]

[Prologue]

Gylfi was the name of a man [...] He called himself Gangleri [...] [he] began his questioning. [...] and [Gangleri] related those events he had seen and heard about. And following his account one person after another told these stories.

But the Æsir then gathered in discussion and [...] rehearsed all the narratives which had been told to him and gave those same names which were previously mentioned to people and places there [in Sweden] [...]

Hár says:

As it says in the spá of the völva [...]

And she [the völva] says these are the names of those dwarfs [...]

The narrative of Gylfaginning opens out into a dialogue, with Gylfi posing questions and the three named Æsir (Hár, Jafnhár, priði) answering them. The hall in which the dialogue takes place, though, turns out to be a multi-media illusion, and doubt is thereby

8 Snorri Sturluson: The Uppsala Edda, p. 6. The attribution of the work to Snorri specifies his activity as that of compilation (setja saman), with only his authorship of Háttatal explicit: "er Snorri hefir ort" ('which Snorri has composed'). In what follows, I assume that Snorri was the author of Gylfaginning.

9 Snorri Sturluson: Gylfaginning, pp. 7f.

10 Snorri Sturluson: Gylfaginning, p. 54.

11 Snorri Sturluson: Gylfaginning, pp. 54f.

12 Snorri Sturluson: Gylfaginning, p. 9.

13 Snorri Sturluson: Gylfaginning, p. 16. 
cast over whether the quoted voices might also be illusory. ${ }^{14}$ As we read, we are hearing voices (as is always the case when we read and part of the cognitive adventure of engaging with the written word); but in what sense can the reader 'believe' those voices? All kinds of tricks occur during the course of the dialogue in Gylfaginning with, in particular, an embedded narrative about Pórr's encounter with Útgarðaloki ending with the scene of their dialogue evaporating before pórr's eyes, a scenario that is duplicated at the end of Gylfi's conversation with the three Æsir, when the hall his visit has taken place in disappears into thin air. ${ }^{15}$

The imbricated plotting of the narrative of Gylfaginning repeatedly resists straightforward logical alignment. What has been conveyed during the wisdom contest is plunged further beyond the verifiable when the questing Gangleri is depicted transmitting what he has seen and heard - "ok segir [Gangleri] pau tíðindi er hann hefir sét ok heyrt. Ok eptir honum sagði hverr maðr öðrum pessar sögur" ${ }^{\text {"16 }}$ - at the same time as his competitors-in-wisdom, the Æsir, launch another discourse in which the very names of the figures in their answers to Gylfi are subsequently assigned to their contemporaries in Sweden: “En Æsir setjask pá á tal ok [...] minnask á pessar frásagnir allar er honum váru sagðar, ok gefa nöfn pessi hin sömu er áðr eru nefnd mönnum [...]." ${ }^{17}$ Almost in anticipation of the complex textual history of his own work, Snorri sets up multiple lines of transmission from the Æsir's account, one disseminated through Gylfi's kingdom somewhere in Sweden based on his recollection and another propagated by the Æsir themselves through soubriquet-Æsir who take on the identities of the figures in the narratives just told.

The effect of so many twists is spectacularly destabilising for the reader. ${ }^{18}$ So much of the ancient eddic verse that has been quoted in support of the responses to Gangleri's questions would have been familiar to the $13^{\text {th }}$-century audience of the text - and served as an index, if not of truth then of authentic, ancient tradition - yet if those quoting it are unreliable speakers, where does that leave the reader and their trust in the assumed author of the work? Myths that were accepted, circulated, and valorised in cultural memory, because their real or supposed age was a sufficient guarantee of their authenticity, are undermined as untruthful in the context of a theologised revision of the past, voiced sporadically by the Æsir and engineered by the narrator in the structure of Gylfaginning.

It is worth pausing here to reflect on the effects of these shifts in speaker as the text leads us through the cascade of quotations. As Roland Barthes asked, when we read a text, 'Who is speaking?'. His response was as follows:

15 Compare Snorri Sturluson: Gylfaginning, pp. 43 and 54.

16 Snorri Sturluson: Gylfaginning, p. 54.

17 Snorri Sturluson: Gylfaginning, p. 54.

18 On this effect, see Glauser 2013. 
We shall never know, for the good reason that writing is the destruction of every voice, of every point of origin. Writing is that neutral, composite, oblique space where every subject slips away, the negative where all identity is lost, starting with the very identity of the body writing. ${ }^{19}$

At a very literal level, much industry has gone into assigning a point of origin for the voice of Snorra Edda and identifying authorial intentions tying portions of the text to the body of the author. One of the implications of "the negative where all identity is lost", however, is that the composite voice that writing creates resists that simple equation, especially when the composite voice masquerades as the many colourful and loquacious identities that we find within Gylfaginning. While the special voice of some works may well meld several indiscernible voices, in a work such as Gylfaginning which foregrounds the particularity of many quoted voices, some voices may also be amplified beyond their weight in words. So many quotations are couched within quotations in this auditory mise en abyme that, at any one moment, a particular voice may seem more commanding than the others around which it echoes. An example of this phenomenon is referenced above, at the point when Hár quotes again from a poem called Völuspá - literally the spá ('prophecy') of the völva ('seeress'), a poem quoted extensively throughout Gylfaginning - and the voice of the völva is projected beyond other voices as she is heard listing mythological details: "Ok pessi segir hon nöfn peira dverganna" ('And she [the völva] says these are the names of those dwarfs'). From within the text, she is presented speaking the very names that Hár ventriloquises, Gangleri reports, and the narrator records.

To return to the cascade of quotations set out earlier, let us look at another example from early on in the dialogue between Gangleri and the three Æsir, at the beginning of the roll-call of gods in which óðinn is introduced ${ }^{20}$ well before the formal introduction of Loki. ${ }^{21}$

$\infty$ Pá mælir priði:

œ [...] svá sem hér er sagt at óðinn mælir sjálfr við pann Ás er Loki heitir: $\infty$ 'CErr ertu Loki [...]'”22

Then Third said:

[...] just as it is said here that óðinn himself spoke to that god who is called Loki: You're mad, Loki [...] 
Here, in response to a question from Gangleri, briði responds by quoting lines that are purported to be the very words Óðinn himself spoke. ${ }^{23}$ One of the effects of this assertion of authenticity is the amplification of a particular voice within the cacophony of quotations within quotations such that the reader temporarily loses any sense of the hierarchical order of the framing voices and therefore of the inferred intellectual argument that what is told to Gangleri may be illusory. Suddenly it is Óðinn's tremendous voice that thunders out, as the gravitational centre of authority shifts within the text. To show this schematically, the hierarchy of authorial voices can be momentarily inverted during this intense instance of eddic quotation:

$\infty$ 'CErr ertu Loki [...]'

œ svá sem hér er sagt at óðinn mælir sjálfr við pann Ás er Loki heitir:

$\infty$ pá mælir briði:

$\infty$ [...] ok segir [Gangleri] bau tíðindi er hann hefir sét ok heyrt. Ok eptir honum sagði hverr maðr öðrum pessar sögur.

œ En Æsir setjask pá á tal ok [...] minnask á pessar frásagnir allar er honum váru sagðar, ok gefa nöfn pessi hin sömu er áðr eru nefnd mönnum ok stöðum peim er par váru [...].

œ Gylfi konungr var maðr [...] Hann nefndisk Gangleri [...] hóf svá mál sitt

$\infty$ [Prologue]

$\infty$ Bók pessi heitir Edda. Hana hefir saman setta Snorri Sturluson [...]

You're mad, Loki [...]

[...] just as it is said here that Óðinn himself spoke to that god who is called Loki:

Then Third said:

[...] and [Gangleri] related those events he had seen and heard about. And following his account one person after another told these stories.

But the Æsir then gathered in discussion and [...] rehearsed all the narratives which had been told to him and gave those same names which were previously mentioned to people and places there [in Sweden] [...]

Gylfi was the name of a man [...] He called himself Gangleri [...] [he] began his questioning.

[Prologue]

This book is called Edda. It has been compiled by Snorri Sturluson [...]

The text of Gylfaginning is a striking example of how the inventive and dislocating effects of verse quotation within a prose account can work, especially of the manner in which

23 The idea that readers are hearing the very words of the gods is promoted elsewhere in the text as well: "Hér máttu heyra í Grímnismálum" ('You can hear about it here in The Words of Grímnir') and "ok enn hefir hann [óðinn] nefnzk á fleiri vega pá er hann var kominn til Geirrøðar konungs" ('and óðinn called himself by various names when he visited King Geirrøðr'). Snorri Sturluson: Gylfaginning, pp. 33 and 21. The deictic marker "hér" ('here') serves to make the connection between explanation and evidence rhetorically palpable. 
the quoted voice can sound louder than the narrating voice, which is itself, of course, a composite voice created by the artifice of writing. To draw in Foucault's observations here as well, we might observe in relation to the effects achieved in Gylfaginning that

[writing] implies an action that is always testing the limits of its regularity, transgressing and reversing an order that it accepts and manipulates. Writing unfolds like a game that inevitably moves beyond its own rules and finally leaves them behind. Thus, the essential basis of this writing is [...] primarily concerned with creating an opening where the writing subject endlessly disappears. ${ }^{24}$

As Óðinn berates Loki, I would argue, briði, Gylfi / Gangleri and the narrator all tumble out of the frame and what sense we have of Snorri-the-author disappears (unless we resolutely and endlessly reinstate him in our reading practice or commentary). As the game that is the text of Gylfaginning unfolds, the writing moves beyond its own rules and the intellectual conceit - that all these myths might be understood as illusory - is momentarily but repeatedly left behind.

The writing subject evanesces even more readily in anonymous works, such as the many sagas about Iceland's past that were written from the $13^{\text {th }}$ century onwards. One of these, Porgils saga ok Haflida, is set in the early decades of the $12^{\text {th }}$ century when literate culture was being established in Iceland; the earliest manuscripts of the work, however, are from some two hundred years later. ${ }^{25}$ The saga is classed among the Samtíðarsögur (sagas of Contemporary Times), many of which are anonymous, although Íslendinga saga, a major work within the compilation manuscripts which record these sagas, is attributed to Snorri Sturluson's nephew, Sturla Pórðarson. ${ }^{26}$ Despite the fact that no author's name was attached to Porgils saga ok Hafliða during its manuscript transmission, many scholars have attempted, unconvincingly, to find a name that might fit, implicitly equating the lack of a named author with a diminution in the text's authority and value. ${ }^{27}$ As mentioned earlier, the authority of saga texts in the medieval period appears to have derived not from authorship by a named person but from the nature and style of the material being transmitted. As such, saga prosimetrum presents a very interesting

Foucault 1977, p. 116.

The saga forms part of the compilation known as Sturlunga saga and is partially preserved in two $14^{\text {th }}$-century manuscripts: Króksfjarðarbók and Reykjarfjarðarbók. As the text of the saga is fragmentary in both, later paper manuscripts preserving copies of the medieval work have been drawn on by editors. See Ursula Brown's (1952, pp. LII-LXII) introduction to her edition of Porgils saga ok Hafliða, for a discussion of the manuscripts of the saga and the rationale for using British Museum Add II, 127 as the basis for her edition.

See Úlfar Bragason 2010.

In the introduction to her edition of the saga, Brown (1952, pp. L-LII) surveys the speculation and concludes: "It is unlikely the author of Porgils saga will ever be identified beyond doubt." 
textual scenario - possibly unique in medieval literature - where traditional material travelled through texts without being tied to a named author while, at the same time, elements of the text were verified by being attributed to named poets. This scenario is most starkly evident in the sagas of Norwegian kings (Konungasögur) where the quotations of stanzas by court poets are deployed in the narrative to corroborate the material presented in prose by the saga narrator. ${ }^{28}$ Poetic quotation is more subtly at play in sagas about the very speakers of the stanzas themselves, the many sagas about Icelanders of the settlement period (Íslendingasögur) and later (Samtíðarsögur).

To date, the quotation of stanzas within saga prose has tended to be analysed in terms of the functional relation of the quotation to the preceding prose, with the inquit taken as a distinguishing signal between so-called 'authenticating' stanzas (introduced by "svá segir [name of poet]" ['as [the poet] says']) and so-called 'situational' stanzas (introduced by "pá kvað [name of saga character]" ['then [the saga character] recited']). ${ }^{29}$ While this functional orientation provides a useful tool in the analysis of saga prosimetrum, it can create a false division in terms of literary effects, since a stanza spoken by an intradiegetic figure in the narrative can also function as authentification. Furthermore, the same kind of stanza could be used by narrators either as verification by a speaker disengaged from the immediate substance of the narrative ('svá segir') or it could be staged as speech within a dramatic encounter in the narrative ('pá kvað'), depending on how the saga author wanted to set the scene. Anonymity cuts across these effects in interesting ways. Eddic poetry, as we saw, could be deployed as quotations of the words of the gods or supernatural figures themselves, with the eddic poet effaced in the process of quotation - the alliterative rhythm and conventions of the eddic mode authenticating the transmitted traditions. When skaldic poetry was quoted within saga prosimetrum, on the other hand, a different array of effects is evident. The quotation of stanzas by named figures in the saga carried with it a straightforward authenticity effect, yet quotation of skaldic stanzas by unnamed poets could also be used to rhetorical advantage by saga narrators, as we shall see..$^{30}$

In saga narratives, quoted stanzas present the words of figures of the past, fixed across time by the forces of metrical form, made audible again to the reader through a rendering of poetic performance. The words of figures of the past are also staged by the narrator as dialogues in prose and while these present a simulacrum of conversations that once took place, they lack the verification that inheres in the form of poetry, especially that in complex metres such as dróttkveett and related metres, which control the

28 See Whaley 1993.

29 This mode of analysis has been proposed by Wolf 1965, Bjarni Einarsson 1974, Whaley 1993 and modified to some extent by Clunies Ross 2005, pp. 77-79.

30 The aesthetics of verse quotation within the Íslendingasögur is the subject of a new collaborative project led by Stefanie Gropper and myself, jointly funded by the DFG and AHRC. 
ordering of syllables through the alliteration of stressed syllables across pairs of lines, demand more or less consistent patterns of internal assonance within the line (hendingar) as well as fixing the numbers of syllables in the line and the number of lines in the stanza. To put it another way, it is the poet who unequivocally authors the wording of a stanza whereas the authorship of the same figure's prose dialogue is more nebulous, crafted as it is by the saga narrator who chooses whether it is cast as direct or indirect speech, how extensive the quotation or reported speech is, and the degree to which it is modified or evaluated by interruptions from the narrator. By way of contrast, it is the norm for entire stanzas to be quoted uninterrupted - and, it may be inferred - unedited.

To a significant extent it is therefore the inherent formal features of skaldic stanzas that serve to enhance their actuality as preserved utterance, even in instances where the historical figure to whom they are linked is unnamed. ${ }^{31}$ porgils saga ok Hafliða preserves seventeen verse quotations, of which seven are spoken by named figures in the saga and ten stanzas (which have much in common with the others in terms of metre and style) are quoted not as utterances attributed to particular speakers but as compositions circulating at the time, thereby participating in the same economy of verification as those stanzas depicted as being the compositions of named figures in the saga. The very first quotations in the saga, which round off the depiction of a lawsuit between the feuding chieftains at the centre of the saga, are introduced as corroborating evidence: par um váru kveđnar vísu pessar ${ }^{32}$ ('These verses were composed about that'). While the three stanzas quoted in succession each covers similar material in terms of content, they are distinguished from one another by their metrical flourishes and probably represent the work of competing poets commemorating Porgils' successful prosecution of a case against his enemies. ${ }^{33}$

Since just one stanza would have been sufficient to verify the account, the narrator's choice to indulge in the metrical and semantic variations on a theme one or more poets have produced on the occasion of the law case is significant. It signals, on the one hand, the narrator's taste for poetic superfluity; and on the other, it is evidence of a disinclination at this stage of the saga to personalise the exchanges or to restage the compositions as a social event, with the speakers identified and a specific setting described. The quotations just flow into the text - "Par um váru kveðnar vísu pessar" composed by passive agents whose voices endow the account with authority but who themselves are reduced to detached, unidentified voices, untethered to any context

31 By referring to the actuality of the stanzas as performed utterance, no inference is made that they are necessarily authentic compositions from the time of the saga's setting, though they are, of course, presented as such.

32 porgils saga ok Hafliða, pp. 11f. All quotations from the saga are from Ursula Brown's edition with the translation informed by her Notes.

33 For a detailed discussion of the use of verse quotation in Porgils saga ok Hafliða, see Quinn 2020. 
of performance. Who speaks here but the constructed voice of authored skaldic tradition, authenticated by rhythm and assonance, a voice that is at once authored and curiously without identity. (The author in this case does not even have an assumed life before their textual death.) Whether or not the saga author might have known the identity or identities of the poets whose stanzas are quoted cannot be ascertained but it is possible that the absence of named speakers was a deliberate textual manoeuvre to maintain the narrator's voice as the dominant narrative channel while exploiting the authenticity effects lent to the narrative by anonymous skaldic quotation. ${ }^{34}$ If so, the narrator cleverly exploited the medium without encumbering the narrative with additional identities whose relations within the saga's network would have required at least some elaboration.

A similar mode of anonymous authentication closes the saga; again anonymous poetic quotation is deployed to clinch an account of a lawsuit: Ok pá er lokit var málum pessum, pá var sú visa kveðin ${ }^{35}$ ('And when this case was finished, then this stanza was composed'). Except that once again a superfluity of anonymous poetic compositions is in evidence, as the inquit is followed by not one stanza but two (both anonymous), and once again the stanzas represent poetic variations on a theme, with some of the same wording repeated between them.

Quotations of stanzas by named figures in the feud narrative are also woven into the dialogue of the saga and presented as integral to the storyline. An example of this is the quotation of a verse by Dórðr Rúfeyjarskáld, who is specifically identified as a poet when he is introduced in the saga. ${ }^{36}$ In this scene in chapter 12, Dórðr asks borgils Oddason about the value of an axe he had been given - and which pórðr coveted, judging it fair compensation for a verse he had previously composed about porgils. The narrative moves easily here between indirect speech, direct poetic recitation and direct speech:

pórðr [...] spyrr, hvers peim pœetti verð øxin, en peir urpu á tvær merkr. Pórðr kvað vísu:

"Metin [er] marka tveggja [...]

Ok fagrslegin fála

fastleggs virð[i] [h]ála

semdi sjá fyr kvæði [...]."

porgils mælti at pórðr skyldi taka landsleigu undir sjálfum sér, en hann sagðisk eiga

lóg til øxarinnar. ${ }^{37}$

34 The element of competition between prose and poetic voices in Old Norse prosimetrum was explored in Quinn 1997.

35 Porgils saga ok Hafliða, p. 43. There is a further example of the anonymous style of quotation midway through the saga: "Ok var petta par um kveðit" ('And this was recited there about it.'). porgils saga ok Hafliða, p. 30.

36 porgils saga ok Hafliða, p. 3.

37 porgils saga ok Hafliða, p. 21. 
Dórðr asked what they thought the axe was worth and they guessed two marks. Pórðr recited a verse: "Valued at two marks [...] And this beautifully wrought axe would be a very fitting gift to a man who values gold for his poem [...]" Porgils said that pórðr might take land rent for himself but declared that he had no right to the axe.

Another crucial scene in the escalation of the feud between porgils and Hafliði Másson involves Porgils' own poetry, bolstered in this instance by his own prose utterance, in a mimetic rendering of the way poetic recitation added gravitas not just to a prose saga, but also - according to the depiction in the saga - to the interactions on the ground between the men on one side of the feud, as Porgils rallies them to action:

Pá tóku margir undir, at pat væri glíkligast, at Porgils mundi ráđa at sinni athǫfnum peira. Рá kvað porgils vísu:

"Munat óssvita ásum

$\operatorname{ar}[\mathrm{n}]$ sprengjand[i] lengi,

pat segi ek, gulls ins gjalla

Gerðr, pinglog[i] verða."

"Ok munum vér ríða verða”, sagði porgils [...]. ${ }^{38}$

Then many responded that it would be best if porgils were to decide on their reaction. Then porgils recited a verse: "The one who makes the eagle burst [warrior] must not for long fail to keep his engagement with the noble men - that I declare, lady of the ringing gold." "And let us ride onwards", said porgils [...].

porgils' stanza is an artful declaration of his own valour, addressed - incongruously in this prosimetric context - to an unnamed woman, one who stood as judge of masculine prowess and, within the convention, was potentially instrumental in facilitating the transmission of it. The anomalous apostrophe highlights the authenticity of the stanza as porgils' own words, unedited by the saga narrator to fit exactly into the context of quotation but prevailing as verification of the chieftain's resolute character as witnessed by his supporters (who, it is to be inferred, should transmit the stanza). But the stanza alone was not enough to tell the story of porgils' retaliation: the saga narrator supplemented the poetic quotation with dialogue as Dorgils spells out exactly how his poetic words translate into action as, in prose, he urges his supporters to ride with him to pursue their cause.

This is an interesting case of an apparently restaged utterance by an identified figure in the saga in the presence of intradiegetic listeners within the saga. The staging of verse as a performance in front of an audience of retainers is evident elsewhere too and underlines a sense that poetic compositions are vitally of their moment, capturing 
attitudes and reactions just as they were expressed at the time they were supposedly first uttered. After porgils seriously injures Hafliði's hand in a skirmish, the narrator describes how Ingimundr the priest, porgils' kinsman and ally, was sent to find out how serious his injuries were, with his response staged in just this way, as the very words that he spoke when greeted on his return to his booth at the thing:

Ok pá er peir kómu heim til búðar porgils, pá váru peir spurðir tíðinda ok eptir erindum sínum. pá kvað Ingimundr prestr:

"Fingr eru brír af peiri, pó skyldi mun fleiri sundr[á] s[æl]lings hendi, slíkt er bọ[g]gr mikill, hoggnir."

Síðan var kvatt var féránsdóms $[. . .]^{39}$

And when they came back to Porgils' booth, they were asked for news about how things had gone. Then Ingimundr the priest recited: "Three fingers were chopped off that hand; that is a serious injury - yet still more could have been choped off the rich man's hand." After that, a court of execution was convened [...].

Boasting of violent mutilation cuts both ways in the prosimetrum of the saga, serving to foreground the aggressive spirit among porgils' band of supporters at the same time as it confirms the extent of Hafliði's injury. The narrator reveals the detail of the injury after describing the successful prosecution of porgils (who is outlawed as a skógarmaðr, or 'man of the wilderness'), as a prelude to the mounting tension of the imminent confiscation court.

A final example demonstrates the same prosimetric style, where a stanza by Ingimundr in praise of porgils is staged not as a detached, ceremonial tribute to a chieftain but as an impromptu partisan declaration during manoeuvres:

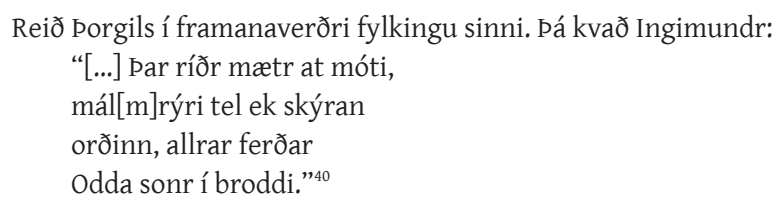

porgils rode at the forefront of his troop. Then Ingimundr recited: “[...] There rides the respected son of Oddi [porgils] to the encounter, at the head of his company. I think the destroyer of weapons [warrior] has become wise." 
Such a stanza would lend authority to the saga narrative however it was contextualised, whether, as here, staged as part of a scene in the narrative or whether as corroborating evidence (had it been introduced "Svá segir Ingimundr", for example, to affirm details mentioned in the preceding prose). Since Ingimundr is an important actor in the feud narrative - and an unashamed partisan - his identification as the author of the stanza adds dimension to the prosimetrum in comparison with, say, the first three stanzas of the saga that were quoted anonymously.

Authorship of quoted stanzas can be seen to be deployed to advantage by the saga narrator, in other words. In circumstances where identification serves to deepen characterisation and nuance the telling of the feud narrative, the narrator identifies the poet of the quoted stanza; where it is the composition itself that is highlighted, anonymity can be convenient. Flexibility in approach is nowhere more obvious in the saga than in the sequence of stanzas quoted within the depiction of the unruly banter that occurs during a wedding feast (chapter 10). In this vivid scene, those on porgils' side of the feud taunt a wedding guest who is a relative of Hafliði's on account of the guest's bad breath. The bullying scene is described in detail and results in the guest, the chieftain pórðr porvaldsson, walking out of the feast. Seven poetic compositions of various lengths are included in the account, with those by Ingimundr - who started it all - and pórðr - who joins in the game in good humour to begin with - attributed to them, while all of the others are anonymously recorded.

[...] Ingimundr prestr laut at sessunaut sínum ok mælti við hann, svá sem hinn spyrði:

[...] pá kveðr pórðr í mót:

[...] pá var petta kveðit til pórðar:

Hér hlær pórðr mjök at pessum kveðlingi ok kveðr í mót pegar:

Pá var petta kveðit:

Dá var petta kveðit:

En er pórðr gekk út, pá var petta kveðit:

(v. 10) $)^{41}$

[...] Ingimundr the priest lent towards his seating companion and spoke, as if he had been asked:

[...] then pórðr said in return:

[...] Then this verse was directed to Pórðr:

pórðr laughs heartily at this verse and immediately retorts [...]

Then this verse was recited [...]

Then this verse was recited [...]

And while Pórðr was walking out, this was recited [...] 
Four of the compositions are not attributed to a named poet, yet they are nonetheless quotable because of their authoritative form, as poetry. ${ }^{42}$ As suggested earlier, while verses like this participate in the same economy of verification as stanzas depicted as being the compositions of named figures in the saga, they travel within the prosimetrum without biographic strings attached: to paraphrase Foucault, authentification did not require reference to the individual in this context. Unlike the first three stanzas quoted in Porgils saga ok Hafliða, however, the anonymous compositions about Pórðr's foul-smelling breath are staged not as detached evidence but as part of a lively interactive scene, albeit one in which the identity of speakers is only sporadically, and pragmatically, revealed. Whether masked or unmasked, the quoted poets speaking through prosimetric texts are significant, their revelations providing a malleable resource for saga narrators to work with.

In this chapter, I have investigated some of the literary effects that could be achieved by medieval Icelandic prosimetrum writers as they exploited the potential of orally transmitted poetry to enrich their prose. Despite the markedly different discourses out of which each work is constituted, both porgils saga ok Hafliða and Gylfaginning demonstrate the ways in which verse quotation provides an 'index of truthfulness' around which narration develops. In both works, the voices speaking according to conventions of poetic composition are rendered authoritative through the performance of quotation, even though the time and place when the rhythmic lines were composed were already separate from the scene of writing and markedly distant, especially in the case of the eddic verse quoted within Snorra Edda.

\section{Bibliography}

\section{Primary Sources}

The First Grammatical Treatise. Diplomatic edition by Hreinn Benediktsson, Reykjavík 1972 (University of Iceland Publications in Linguistics 1).

Snorri Sturluson: Edda. Prologue and Gylfaginning. Critical edition by Anthony Faulkes, London 1988.

Snorri Sturluson: The Uppsala Edda: DG 114 to. Critical edition by Heimir Pálsson, London 2012. porgils saga ok Hafliða. Critical edition by Ursula Brown, Oxford 1952.

42 This scene, in which pórðr is in fact able to track down the identity of the speaker of v. 9 after it has been spoken, is analysed in more detail in Quinn 2020. 


\section{Secondary Sources}

Barthes 1977 = Barthes, Roland: Death of the Author, in: Image Music Text, tr. by Stephen Heath, London 1977, pp. 142-148 [1 $1^{\text {st }}$ ed. in French as La Mort d'Auteur, 1968 (Manteia 5)].

Bjarni Einarsson 1974 = Bjarni Einarsson: On the Rôle of Verse in Saga-Literature, in: Mediaeval Scandinavia 7 (1974), pp. 118-125.

Brown 1952 = Brown, Ursula: Introduction, in: Porgils saga ok Hafliða. Critical ed. by Ursula Brown, Oxford 1952, pp. IX-LXII.

Clunies Ross 2005 = Clunies Ross, Margaret: A History of Old Norse Poetry and Poetics, Cambridge 2005.

Foucault 1977 = Foucault, Michel: What is an Author? in: Michel Foucault. Language, Counter-Memory, Practice. Selected Essays and Interviews, tr. by Donald F. Bouchard / Sherry Simon, Ithaca 1977, pp. 113-138 [1 $1^{\text {st }}$ ed. in French as Qu'est-ce qu'un auteur? in: Dits Ecrits I, texte no. 69, 1969].

Glauser 2009 = Glauser, Jürg: Sinnestäuschungen: Medialitätskonzepte in der Prosa-Edda, in: Margrét Eggertsdóttir (ed.): Grepaminni: Rit til heiðurs Vésteini Ólasyni sjötugum, Reykjavík 2009, pp. 165-174.

Glauser 2013 = Glauser, Jürg: Unheilige Bücher. Zur Implosion mythischen Erzählens in der Prosa-Edda, in: Das Mittelalter. Perspektiven mediävistischer Forschung 18 (2013), pp. 106-121.

Guðrún Nordal 2001 = Guðrún Nordal: Tools of Literacy: The Role of Skaldic Verse in Icelandic Textual Culture of the Twelfth and Thirteenth Centuries, Toronto 2001.

Jesch 2005 = Jesch, Judith: Skaldic Verse, A Case of Literacy Avant la Lettre?, in: Pernille Hermann (ed.): Literacy in Medieval and Early Modern Scandinavian Culture, Odense 2005 (Viking Collection 16), pp. 187-210.

Quinn 1997 = Quinn, Judy: “Ok er petta upphaf": First Stanza Quotation in Old Norse Prosimetrum, in: Alvíssmál 7 (1997), pp. 61-80.

Quinn 2020 = Quinn, Judy: Orality, textuality and performance, in: Massimiliano Bampi / Carolyne Larrington / Sif Rikharðsdóttir (eds.): A Critical Companion to Old Norse Literary Genre, Cambridge 2020, pp. 73-88.

Quinn 2021 = Quinn, Judy: Snorra Edda, in: John McKinnell (ed.): Written Sources (Pre-Christian Religions of the North 2), Turnhout 2021 (forthcoming).

Úlfar Bragason 2010 = Úlfar Bragason: Ætt og saga: Um frásagnarfræði Sturlungu eða Íslendinga sögu hinnar miklu, Reykjavík 2010.

Wanner 2008 = Wanner, Kevin: Snorri Sturluson and the Edda. The Conversion of Cultural Capital in Medieval Scandinavia, Toronto 2008.

Whaley 1993 = Whaley, Diana: Skalds and Situational Verses in Heimskringla, in: Alois Wolf (ed.): Snorri Sturluson. Kolloquium anläßlich der 750. Wiederkehr seines Todestages, Tübingen 1993, pp. 245266.

Wolf 1965 = Wolf, Alois: Zur Rolle der Vísur in der altnordischen Prosa, in: Osmund Menghin / Hermann M. Ölberg (eds.): Festschrift für Leonhard C. Frans zum 70. Geburtstag, Innsbruck 1965 (Innsbrucker Beiträge zur Kulturwissenschaft 11), pp. 459-484. 
